\title{
14
}

\section{La salvaguarda del patrimonio cofrade malagueño}

\author{
Andrés Camino Romero \\ Director de la revista La Saeta \\ Trinidad García-Herrera Pérez-Bryan \\ Directora del Archivo de la Agrupación de Cofradías \\ Jorge Luque Fernández \\ Director del museo de la Semana Santa Jesús \\ Castellanos
}

Hoy día es una realidad más que palpable que las cofradías y hermandades malacitanas, tanto penitenciales como letíficas, han tomado plena conciencia del estado de conservación de sus imágenes titulares y del patrimonio procesional y documental que atesoran, confiando en especialistas la restauración de la talla en cuestión, la pieza dañada o el legajo en peligro de desaparición. Antaño las llamadas "restauraciones", especialmente las referentes a la imaginería, solían confiarse a personas poco cualificadas o con falta de preparación académica, dejando bastante que desear los trabajos que efectuaban, aunque no dudamos de que lo hicieran con la mejor de las voluntades. Estas tomas de decisiones se debían, principalmente, a la falta de conocimiento y de medios económicos, circunstancias que arrastraron a las corporaciones penitenciales a optar por esta salida en etapas aún cercanas en el tiempo. Como decimos, esta mentalidad, por fortuna, ha ido cambiando y para bien con el paso del tiempo y los miembros de las actuales juntas de gobierno, previa autorización del Departamento de Patrimonio Cultural y Artístico de la Diócesis de Málaga, confían estos laboriosos trabajos a verdaderos profesionales. Haciendo un somero repaso de las intervenciones llevadas a cabo por el Instituto Andaluz del Patrimonio Histórico (IAPH) a imágenes de cristos y vírgenes de la Semana Santa de Málaga, mencionamos las del Santísimo Cristo de la Agonía (1996-1997), Nuestro Padre Jesús del Rescate (2003), María Santísima de Gracia (2004), Santísimo Cristo Resucitado (2005-2006), María Santísima de los Dolores de la Expiración (20072008), Santísimo Cristo de la Buena Muerte y Ánimas (2008), Santísimo Cristo de Ánimas de Ciegos (2009), Santo Cristo Coronado de Espinas (2017), Nuestra Señora de Gracia y Esperanza (2017), entre otros.

Estos han sido algunos de los trabajos acometidos por el prestigioso organismo dependiente de la Consejería de Cultura de la Junta de Andalucía, pero hay otras cofradias que, sin embargo, han delegado estas minuciosas y delicadas labores a empresas especializadas tales como Quibla Restauraciones, ocupándose del arreglo de María Magdalena (2007), talla que figura a los pies del Santísimo Cristo de la Buena Muerte y Ánimas; o a reputados escultores y entendidos en la materia, véanse, por citar tres claros ejemplos, los del profesor Juan Manuel Miñarro López, restaurador de Nuestro Padre Jesús de Azotes y Columna (2005-2006), del Santo Cristo de la Vera Cruz y Sangre (2011-2012) y de Nuestro Padre Jesús Cautivo (2017); de Luis Álvarez Duarte, de 


\section{"Vamos por el buen camino y nos congratulamos de que cualquier cuestión artística se someta al dictamen y criterio científicos"}

María Santísima de la Esperanza (2009), de María Santísima de la Paz (2012), del Señor de la Sagrada Cena Sacramental (2013) y de María Santísima de la Salud (2016); del licenciado en Bellas Artes en la especialidad de Restauración Escultórica y Pictórica, Francisco Naranjo Beltrán, de Nuestra Señora de los Dolores del Puente (2015) y de Nuestro Padre Jesús de los Pasos en el Monte Calvario (2018).

Independientemente de los trabajos emprendidos por el IAPH para el mundo de las cofradías y hermandades de la ciudad de Málaga, esta institución también ha asumido otro tipo de encargo, como el de la recuperación del (incompleto) lienzo de Los Desposorios de la Virgen (2014-2016), obra atribuida al pintor flamenco Cornelio de Vos (1585-1651) y que pertenecía a la extinta Hermandad de la Santa Caridad de Nuestro Señor Jesucristo, cuya ubicación actual se encuentra en un altar de la iglesia de San Julián, sede administrativa y cultual de la Agrupación de Cofradías. Igualmente, y ya en nuestros días, el baldaquino o templete barroco de madera dorada, donde queda entronizada

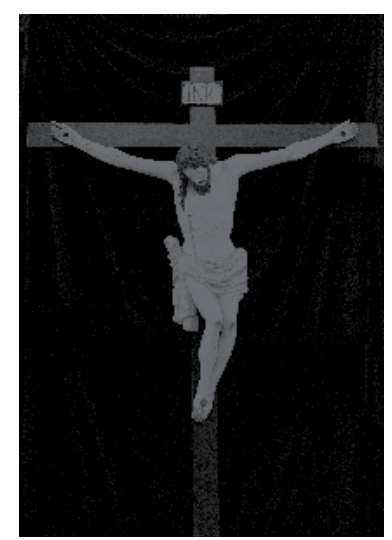

Santísimo Cristo de Ánimas de Ciegos. Iglesia de San Juan Bautista (Málaga). Foto José Alarcón Capilla tradicionalmente la efigie de Santa María de la Victoria en el camarín de su basílica-santuario de igual nombre, está siendo restaurado con motivo del 150 aniversario de la declaración de patrona de la Diócesis y de la ciudad de Málaga (18672017) en las dependencias del IAPH, enclavado en el antiguo monasterio de la Cartuja de Santa María de las Cuevas, de Sevilla.

Estamos convencidos, tras lo expuesto, de que vamos por el buen camino y nos congratulamos de que cualquier cuestión artística se someta al dictamen y criterio científicos por parte de los expertos para la preservación de nuestro preciado patrimonio cofrade que goza, en la actualidad, de un excelente estado de salud.

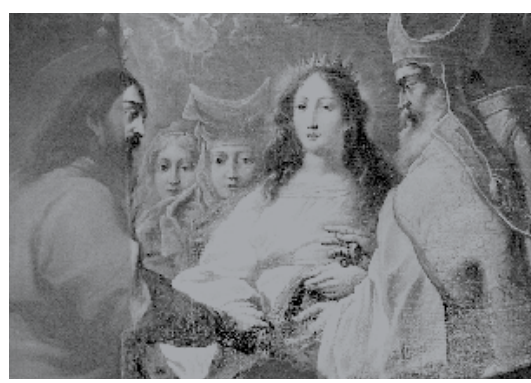

Los Desposorios de la Virgen. Iglesia de San Julián (Málaga) Foto José Alarcón Capilla

\section{Fuentes consultadas}

Colección documental del Archivo de la Agrupación de Cofradías.

Colección de la revista La Saeta, órgano oficial de la Agrupación de Cofradías.

Colección de boletines de cofradías y hermandades agrupadas.

Prensa local: Sur, La Opinión de Málaga y Málaga Hoy. 